THE PROBLEM OF TRUST 



\section{THE PROBLEM OF TRUST}

Adam B. Seligman

PRINCETON UNIVERSITY PRESS PRINCETON, NEW JERSEY 


\section{Copyright $(\subset) 1997$ by Princeton University Press}

Published by Princeton University Press, 41 William Street,

Princeton, New Jersey 08540

In the United Kingdom: Princeton University Press, Chichester, West Sussex

All Rights Reserved

Second printing, and first paperback printing, 2000

Paperback ISBN 0-691-05020-1

\section{The Library of Congress has cataloged the cloth edition of this book as follows}

Seligman, A.

The problem of trust / Adam B. Seligman

p. $\mathrm{cm}$.

Includes bibliographical references and index.

ISBN 0-691-01242-3 (cl : alk. paper)

1. Social interaction. 2. Trust (Psychology) 3. Social role. I. Title.

HM291.S3952 1997

96-51589

$302^{\prime} .17-\mathrm{dc} 21$

CIP

This book has been composed in Times Roman

The paper used in this publication meets the minimum requirements of ANSI/NISO Z39.48-1992 (R 1997) (Permanence of Paper)

http://pup.princeton.edu

Printed in the United States of America

10987655432 